\title{
The Value of Producing Food, Energy, and Ecosystem Services within an Agro- Ecosystem
}

\begin{abstract}
Agricultural ecosystems produce food, fiber, and nonmarketed ecosystem services (ES). Agriculture also typically involves high negative external costs associated with, for example, fossil fuel use. We estimated, via fieldscale ecological monitoring and economic value-transfer methods, the market and nonmarket ES value of a combined food and energy (CFE) agro-ecosystem that simultaneously produces food, fodder, and bioenergy. Such novel CFE agro-ecosystems can provide a significantly increased net crop, energy, and nonmarketed ES compared with conventional agriculture, and require markedly less fossil-based inputs. Extrapolated to the European scale, the value of nonmarket ES from the CFE system exceeds current European farm subsidy payments. Such integrated food and bioenergy systems can thus provide environmental value for money for European Union farming and nonfarming communities.
\end{abstract}

\section{INTRODUCTION}

Ecosystem services (ES) are the benefits humans derive from ecological processes and the ecosystem function. By recognizing the value of ES, we accept that our largely nonmarketed ecological wealth underpins our marketed economic wealth. ES from agriculture have hitherto been assigned relatively low values $(1,2)$ when compared with other terrestrial and aquatic ecosystems, partly because of a lack of data. However, it is important to gain a more accurate estimate of the ES from agriculture, because agro-ecosystems cover between $28 \%$ and $37 \%$ of the Earth's land surface and are divided about $70: 30$ between pastures and crops (3). Although agricultural ecosystems may have low ES values per unit area when compared with other ecosystems, such as estuaries and wetlands (1), they offer the best chance of increasing global ES via definition of appropriate goals for agriculture and the use of landmanagement regimes that favor the ES provision. Agriculture can be considered the largest ecological experiment on Earth, with a large potential to damage global ES but also to promote them via ecologically informed approaches to the design of agro-ecosystems that value both marketed and nonmarketed ES $(2,4)$. It is difficult to see how global ES can increase without significant improvements in ES from farming, given the proportion of the Earth's land devoted to agriculture and because its ES provision has been driven to a low level (1) that improvements can readily be achieved.

Earlier studies (1) recognized $17 \mathrm{ES}$, but estimated the value of only three for agricultural systems (pollination, biological control, and food production), partly because of limited data Agricultural systems provide several other ES (5-7), and the level of ES provision achievable by agriculture is largely governed by the intensity of the use and diversity of crop land (8). Assessment of ES from managed landscapes, for example, farming, involves aggregation of these intermediary ES (9). Usually, it is believed that the total value of farm product involves the value of ES, but it is not the case $(9,10)$. It is a key area of debate in the valuation of ES. ES from agro-ecosystems also have to take account of the calculated negative effects (external costs) of agriculture (11) to derive the net ES from farming. This study avoids double counting and addresses external costs in calculating the value of ES in agro-ecosystems.

Coincidental with the issue of ES from agroecosystems, there is a developing interest in using agricultural land for the production of biofuels (12) such that their production is as sustainable as possible. Such a requirement invites the design of new systems of primary production that ensures a positive net carbon sequestration, are species diverse have low inputs, and provide a suite of ES. We describe a novel combined food and energy (CFE) producing agro-ecosystem that meets the above requirements for sustainability by using nonfood hedgerows as sources of biodiversity and biofuel. We identified, quantified, and valued ES from this new production system and refer to this concept as combined food, energy, and ecosystem services (CFEES).

The CFE system on which our work is based was established to create an agro-ecosystem that was a net energy producer, with the system producing more energy in the form of renewable biomass than consumed in the planting, growing, and harvesting of the food and fodder. The bioenergy component is represented by belts of fast-growing trees (willows, alder, and hazel) that are planted orthogonally to fields that contain cereal and pasture crops. Since its inception in 1995, the CFE system has been monitored for a range of ecological indicators, which include biomass and crop yields, energy balance, carbon sequestration, nitrogen $(\mathrm{N})$ availability, and biological control of pests. The CFE system is managed organically, meaning that biocides and inorganic $\mathrm{N}$ are not used. An overview of the differences between the CFE system and conventional cropping systems in Denmark (Table 1) shows the main differences to be that CFE input energy is lower than in conventional farming; it does not use mineral fertilizer and uses lower amounts of organic fertilizer. Neither biocides nor irrigation are used.

After deriving field-based estimates of the ES value, we extrapolated our results to $i$ ) estimate the current ES value of the 25 European Union (EU25) countries' conventional farming, ii) determine how this ES value might change, given a move toward CFE and other kinds of agro-ecosystems with deliberately enhanced ES, and iii) determine the relation between European agricultural ES value and current EU societal support for farming.

In the following material, we present and discuss concepts, methods, and assumptions used in measuring and calculating the ES from the CFE system. We then present our extrapolation methods for European scales and end with the calculation of ES in relation to agricultural subsidies within the EU. Estimating the ES of EU agriculture requires a far more nuanced and regionally based approach than we attempted here. This is a first try at capturing the ES values of EC farming and how it may be affected by CFE-life systems. Our underlying ES 
Table 1. Ranges of inputs and outputs for conventional arable cropping systems for cereals and fodder crops in Denmark and the combined food and energy (CFE) system.

\begin{tabular}{|c|c|c|}
\hline & Conventional arable (source) & CFE system \\
\hline $\begin{array}{l}\text { Inputs }\left(\mathrm{ha}^{-1} \mathrm{y}^{-1}\right) \\
\text { Energy }(\mathrm{GJ}) \\
\text { Applied industrial } \mathrm{N} \text { fertilizer }(\mathrm{kg}) \\
\text { Applied organic } \mathrm{N} \text { fertilizer }(\mathrm{kg}) \\
\text { Insecticides }(\mathrm{kg}) \\
\text { Fungicides }(\mathrm{kg}) \\
\text { Herbicides }(\mathrm{kg}) \\
\text { Irrigation }(\mathrm{m} 3)\end{array}$ & $\begin{array}{c}19(13) \\
110-204(13) \\
44(13) \\
0.010-0.022(14) \\
0.28-0.33(14) \\
0.98-1.08(14) \\
710(14)\end{array}$ & $\begin{array}{c}15 \text { (own calculations) } \\
20 \text { (own calculations) } \\
- \\
- \\
-\end{array}$ \\
\hline $\begin{array}{l}\left.\text { Outputs (ha }{ }^{-1} y^{-1}\right) \\
\text { Energy (GJ) } \\
\text { Grain (t dry matter) } \\
\text { Fodder (t dry matter) } \\
\text { Biofuels (t dry matter) } \\
\text { Set-aside area (\%) }\end{array}$ & $\begin{array}{c}94(15) \\
5.9-8.5(16) \\
32(15) \\
5.8(15) \\
12(15)\end{array}$ & $\begin{array}{r}119 \text { (own calculations) } \\
4.1-5.7 \text { (own calculations) } \\
10.2-10.7 \text { (own calculations) } \\
6.1 \text { (own calculations) } \\
10 \text { (own calculations) }\end{array}$ \\
\hline
\end{tabular}

estimates are uncertain and should only be considered order-ofmagnitude estimates.

\section{MATERIALS AND METHODS}

\section{The CFE System: Study Site, Cropping Pattern, and Management}

The CFE study site was at the experimental farm of the former Royal Veterinary and Agricultural University, 2630 Taastrup, Denmark. Since 1 January 2007, the farm has been part of the Faculty of Life Sciences of the University of Copenhagen, Denmark. The latitude of the CFE site is $55.1^{\circ} \mathrm{N}$, it sits $130 \mathrm{~m}$ above sea level, and the CFE system was planted in May 1995. The CFE system consists of 10.1 ha of arable food (barley and wheat) and a pasture fodder crop (clover-grass) and ca. 1 ha of biofuels, which consists of four belts of fast-growing trees (Fig. 1). An aerial and a ground level picture are shown in Figures 2 and 3 , respectively. The biomass belts are $11-\mathrm{m}$-wide rows of clonally mixed fast-growing bush willows (Salix spp.). On one side of the central. willow rows are two rows of alder trees and, on the other side, two rows of hazel bushes. The alder (Alnus rubra) fixes $\mathrm{N}$, and the hazel (Corylus spp.) is attractive to predatory insects. The trees in the belts were established as five double rows, with the trees planted with a within-row spacing of $0.5 \mathrm{~m}$ and a between-row distance of $0.7 \mathrm{~m}$. Each pair of rows is $1.3 \mathrm{~m}$ from the next one, which gives a planting density of 20000 trees ha ${ }^{-1}$. The biomass belts are harvested and chipped

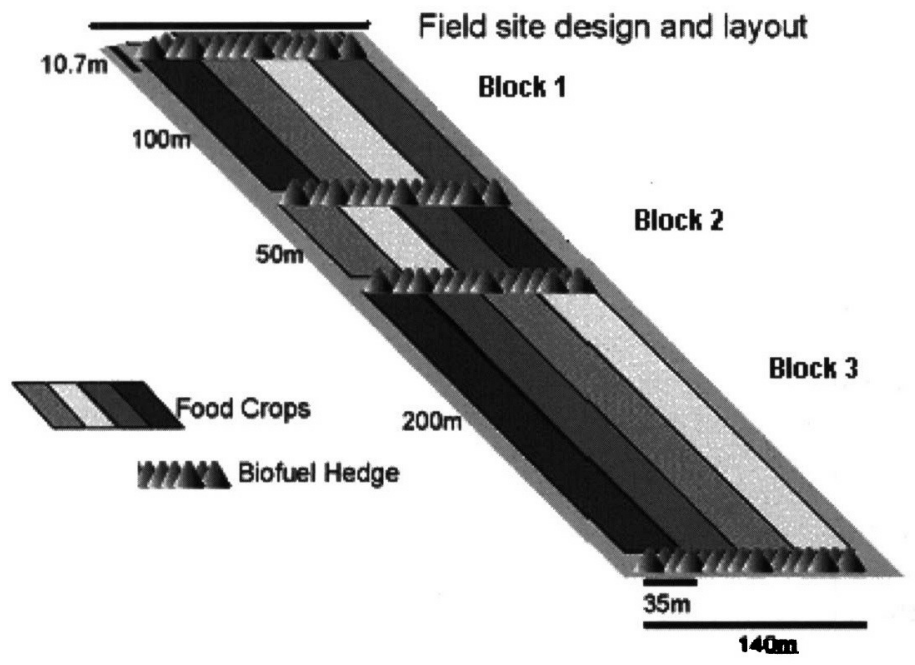

Figure 1. A diagram of the CFE system for organic food and energy production at the University of Copenhagen, Denmark. every 4-5 y, and the wood chips are taken to a nearby heat and power station for the production of heat and electricity.

The food and fodder crops grown between the biomass belts are harvested annually. The crop rotation is one field of barley undersown with clover, two fields of clover-grass, and one of wheat, thus making the percentage area division of the CFE system (pasture : crops : biomass) $45: 45: 10$, although $50 \%$ of the crop component (barley) is undersown with $\mathrm{N}$ fixing clover. The CFE system has been in this rotation since 2000; previously, oats and fodder beets were produced, from 1995 to 2000. The CFE system is organically managed, that is, without the use of biocides and with the nutrient sources coming only from biological $\mathbf{N}$ fixation and the recycling of animal manure. Different distances exist between the biomass rows $(50 \mathrm{~m}, 100 \mathrm{~m}$, and $200 \mathrm{~m})$ to allow the effects of spatial separation and scale to be investigated within the system, although this has not been a goal in the current study.

\section{Calculation of the ES of Agroecosystems and the CFE System}

The calculations were made in two ways. First, to estimate the possible ES value of cropland if it were managed in such a way as to provide a range of ES, we took the ecosystem service valuations presented in Table 2 of Costanza et al. (1) and reasoned that a more multifunctional cropping system could contribute other ES than pollination, biological control, and food production, as suggested in Costanza et al. (1) (Table 2). By using only the three above-mentioned ES led to an ES value of cropland of USD $92 \mathrm{ha}^{-1} \mathrm{y}^{-1}$ (1). To derive monetary values of additional ES that can be attributed to agroecosystems, we averaged the ES values from the other terrestrial biomes given in Costanza et al. (1), and these ES values are presented in Table 2. We see the resulting "top down" ES valuation for a

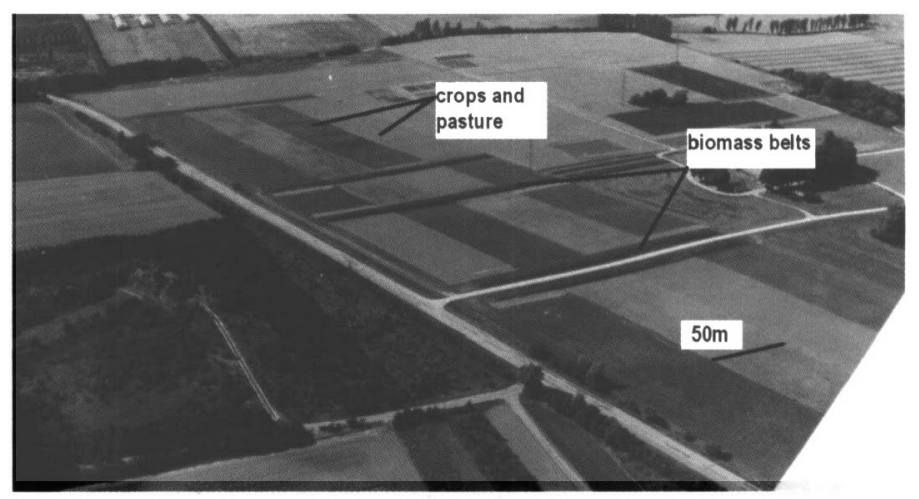

Figure 2. An aerlal photograph of the CFE system at the University of Copenhagen, Denmark. (Photo: J. Porter) 


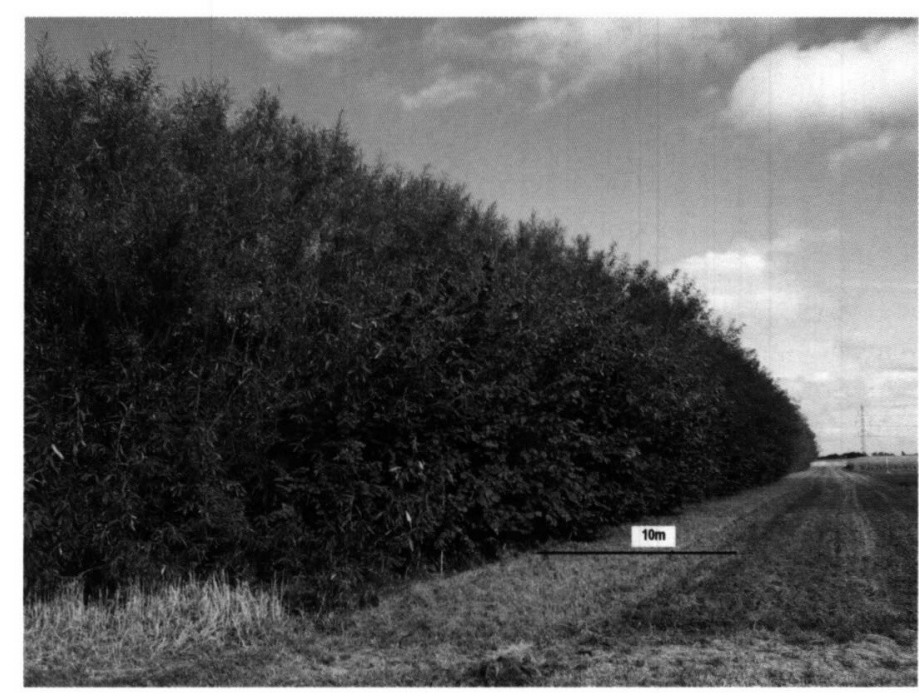

Figure 3. An external view of one of the biomass energy rows and part of the accompanying food crop area within the CFE system at the University of Copenhagen, Denmark. (Photo: J. Porter)

multifunctional cropland as being one that we can compare with the more detailed "bottom-up" estimate made by using the second, field-based, method that is described below.

In the second method, we monitored a range of ecological processes in the CFE system as an example of a field-based multifunctional agroecosystem and made monetary evaluations of the ES from the separate components of the CFE system (pasture, cereals, and biomass) and the CFE as a whole, taking account of the relative areas of the three components.

\section{Field Assessment of ES in CFE System}

ES associated with the CFE system were assessed by field monitoring and assessment methods in June 2006 (10). Field monitoring was done in the pasture, cereals, and biomass belts (Table 3). Economic value (2006 USD prices) of each ES was then calculated (Table 3 ) for three categories: crops, pastures, and biomass belts in the CFE system plus the CFE system as a whole, taking account of the percentage $(45 \%$, crop; $45 \%$, pasture; $10 \%$, biomass) spatial division of the three components in the system. The total economic value of ES was calculated by summing the total of all individual $\mathrm{ES}_{\mathrm{n}}$ values measured per category (17):

$$
\mathrm{ES}_{\text {total }}=\sum \mathrm{ES}_{\mathrm{n}}=\sum \mathrm{ES}_{\text {market }}+\sum \mathrm{ES}_{\text {nonmarket }}
$$

The $\mathrm{ES}_{\mathrm{n}}$ is the following: ES1, biological control of pests; ES2, $\mathrm{N}$ regulation that comprised $\mathrm{N}$ fixation and mineralization for crops and microorganisms; ES3, soil formation by earthworms; ES4, food and forage production (crops and pasture); ES5, raw material production (biomass); ES6, soil carbon accumulation; ES7, hydrological flow into ground water reserves; ES8, landscape aesthetics; and ES9, pollination by wild pollinators.

$\mathbf{E S}_{\text {market }}$ in Eq. 1 includes the market economic value of produced food, forage (ES4), and biomass (ES5), because these are the only two for which products are traded by farmers in the market place. The rest of ES $_{\text {total }}$ in Eq. 1 is derived nonmarket services (18), and the methods used to estimate their economic value are described in the following section.

Biological Control of Pests (ES1). Aphids are the main cereal pests in Denmark and are normally controlled by insecticides (chemical control). The most common aphids that attack cereals are the bird-cherry aphid (Rhopalosiphum padi L.), the grain aphid (Sitobion avenae F.), and the rose-grain aphid (Metopolophium dirhodum Walker). We used live grain
Table 2. Average noncropland ecosystem service (ES) values for terrestrial biomes (from Table 2 in Costanza et al. [1]).

ES Value (USD ha-1 $\mathrm{y}^{-1}$ )

GHG regulation*

Climate regulation

Disturbance regulation

Water regulation

Water supply*

Erosion contro

Soil formation ${ }^{*}$

Nutrient regulation*

Waste treatment

Pollination*

Biological control*

Habitat/refugia

Food production

Raw materials*

Genetic resource

Recreation and aesthetic ${ }^{\star}$

Total

135

141

$\frac{1}{11}$

6
123
8

8
641

- 14

24

304

54

132

273

1866

* ES is included in the CFE system.

aphids ( $S$. avenae) and blowfly eggs as simulated baits for predators to assess the extent of biological control of live aphids and dipteran pests, such as the wheat bulb fly Delia coarctata (Fallen), which lays its eggs on the soil. Predation was assessed in selected fields during June 2006. We used a baseline aphid density of $10 \cdot\left(25 \mathrm{~cm}^{2}\right)^{-1}$ for arable land $(19,20)$ and a density of 8 per $25 \mathrm{~cm}^{2}$ for the blowfly eggs (21). The predation rate was assessed by pinning $25-\mathrm{cm}^{2}$ water-proof sandpaper squares pinned to the soil surface with wooden toothpicks $(22,23)$. Live aphids (dorsal side uppermost) and blowfly eggs were glued onto the sandpaper (P150, Norton) by using 3M repositionable glue in a grid pattern with $1 \mathrm{~cm}$ between aphids. The sandpaper sheets were pinned at the field boundary, the field center, and midway between the two, in two transects $(2 \mathrm{~m}$ apart) in each field, and had a $225-\mathrm{cm}^{2}$ metal plate supported $10 \mathrm{~cm}$ above them to protect them from rain. The predation rate was calculated from the removal of prey per 24-hr period during the study periods. The economic value of this unmanipulated biological control of aphids was estimated by using the avoided cost $(\mathrm{AC})(24,25)$ of pesticide applications, based on their cost in Denmark to control aphids.

To calculate an economic value of aphid predation, three densities were used: density 1 (10 aphids $\cdot\left[25 \mathrm{~cm}^{2}\right]^{-1}$, as above), density 2 ( 7.5 aphids $\left.\cdot\left[25 \mathrm{~cm}^{2}\right]^{-1}\right)$, and density 3 (6.25 aphids. $\left.\left[25 \mathrm{~cm}^{2}\right]^{-1}\right)$. Our economic threshold for biological control was 3-5 aphids per cereal shoot for $S$. avenae, Etopolophium dirhodum, and $R$. padi in wheat fields $(26,27)$, which we converted to a unit area measure, giving an economic threshold of five aphids $\cdot\left(25 \mathrm{~cm}^{2}\right)^{-1}$ based on the numbers of shoots per unit area. For each of the three densities, the number of aphids and eggs consumed by the soil-surface predators based on the predation rate in the field was calculated. Economic value, based on $\mathrm{AC}$, was assigned to the fields in which the predation rate was able to bring the pest population below the economic threshold. The economic value of ES1 was attributed to the biomass belts and pasture, because they provide refuge and shelter to the soil surface and to other predators.

The cost of pesticides used on Danish conventional arable farms to control aphids is USD $6 \mathrm{ha}^{-1}$ application $^{-1}$ and for bulb fly is USD $30 \mathrm{ha}^{-1}$ application ${ }^{-1}$ (26) (2006 prices). Our economic estimates of the value of aphid biological control were based on an "instantaneous" ( $24 \mathrm{hr}$ ) assessment of a complex predation process, but ESl was valued in terms of $\mathrm{AC}$, on a hr $\mathrm{y}^{-1}$ basis. These estimates are within the reported range in previous study (10). We assumed that when the instantaneous reduction of pest numbers by predators over $24 \mathrm{hr}$ reduced the 
population below the economic threshold level and that this is equivalent to two effective pesticide application per year for each pest type.

$N$ Regulation ( $E S 2)$ ). $\mathrm{N}$ regulation comprises $\mathrm{N}$ fixation of atmospheric $\mathbf{N}$ into organically bound $\mathrm{N}$ by the legume clover and the Frankia species red alder in the CFE system and $N$ mineralization from organic to mineral forms of $\mathrm{N}$. Total fixed $\mathrm{N}$ is used by soil microorganisms and plants in a proportion of $70: 30$ (28). Our economic valuation of $\mathrm{N}$ regulation includes both $\mathrm{N}$ used by microorganisms and plants because this permits a comparison with data presented in Costanza et al. (1) and because microorganisms are important components of an agroecosystem. To derive the value of ES2 to the separate crops, fodder and biomass components of the CFE system, the total value of ES2 has to be multiplied by 0.3 . Based on a price of USD $0.63 \mathrm{~kg}^{-1} \mathrm{~N}$, the commercial price of ammonium nitrate fertilizer in Denmark, the calculated amounts of mineralized $\mathbf{N}$ fixed into the separate components of the CFE system are 277 $\mathrm{kg} \mathrm{ha}^{-1}$ (pastures), $143 \mathrm{~kg} \mathrm{ha}^{-1}$ (crops), and $10 \mathrm{~kg} \mathrm{ha}^{-1}$ (biomass). Such values for the pasture and crop components are well within the range found by experimental studies in Denmark $(28,29)$. Total fixation into microorganisms plus the three plant components of the CFE system were calculated as $690 \mathrm{~kg} \mathrm{ha}^{-1}$ (pastures), $345 \mathrm{~kg} \mathrm{ha}^{-1}$ (crops), and $24 \mathrm{~kg} \mathrm{ha}^{-1}$ (biomass) (30).

Mineralization of plant nutrients was assessed at each site by using bait-lamina probes $(31,32)$. Probes were made in a workshop and were 16-cm-long, 0.6-cm-broad, and 1-mm-thick strips of rigid plastic, with sixteen $2-\mathrm{mm}$ holes (33). These were filled with a gel that comprised (by weight): cellulose $(65 \%)$, agar-agar (15\%), bentonite (10\%), and wheat bran (10\%). This mixture matches the key constituents of dead plant material on or in the soil (33). They were inserted into the soil at the same locations as the predation facsimiles described above (ES1). The probes were left in the ground for 10 days in June 2006. Soil microorganisms and invertebrates consume the "bait," and the number of holes that are empty (partially or fully) gives a relative measurement of the percentage of $\mathrm{N}$ mineralization (34 37). The economic value of plant nutrient mineralization provided by soil microorganisms and invertebrates was assessed by using data on mineralization of organic matter obtained from field experiments (36).

$$
\mathrm{N}_{\min }=n \cdot b \cdot v \cdot k \cdot 10^{-3} \mathrm{~kg}
$$

$\mathrm{N}_{\min }=$ amount of $\mathrm{N}$ mineralized, $n=$ total amount of $\mathrm{N}(\%)$ in soil, $b=$ bulk density of soil $\left(\mathrm{g} \mathrm{cm}^{-3}\right), v=$ volume of soil $\left(\mathrm{cm}^{3}\right)$, $k=$ percentage mineralization (\%). The percentage of organic matter mineralized in each field was calculated from this equation by using the nutrient mineralization rate from the baitlamina probes. The total amount of $\mathrm{N}$ mineralized was estimated by using Eq. 2 and was valued at USD $0.63 \mathrm{~kg}^{-1}$ from the commercial price of ammonium nitrate in Denmark. This estimation assumes that, if there is no soil $\mathrm{N}$, then we would have to provide this amount of $\mathrm{N}$ to maintain productivity. The estimates of economic value of $\mathrm{N}$ regulation obtained in this study are similar to the results reported in earlier study (10).

Soil Formation (ES3). Soil formation was assumed to be closely linked to the activities of earthworms and thus dependent on earthworm density (37). Earthworm density was assessed to estimate the quantity of soil formed ha $\mathrm{h}^{-1} \mathrm{y}^{-1}$. Sampling was done during the spring (April 2006), because earthworm populations are generally highest at that time (38). Four $25-\mathrm{cm} \times 25-\mathrm{cm} \times 25-\mathrm{cm}$ soil samples were taken from each site by using a spade and by avoiding field edges and double cultivation areas (39). The soil was spread onto a $2-\mathrm{m}^{2}$ polythene sheet, and earthworms were extracted by hand and placed in a collection jar. The samples from each site were stored in the dark at $10^{\circ} \mathrm{C}$ before sorting for age class and species. The economic value of earthworms in soil formation was calculated based on the assumptions that the mean biomass of an earthworm is $0.2 \mathrm{~g}(40,41)$ and that $1000 \mathrm{~kg}$ of earthworms forms $1000 \mathrm{~kg}$ of soil $\mathrm{ha}^{-1} \mathrm{y}^{-1}$ (42). Thus, the amount of top soil created was calculated by multiplying earthworm mass by the price of top soil in Denmark, that is, USD $53.6 \mathrm{t}^{-1}$. The values are within the reported range of soil formation values in the literature (10).

Table 3. The monetary value and field assessment of ES in pastures, cereals, biomass belts, and the CFE system.

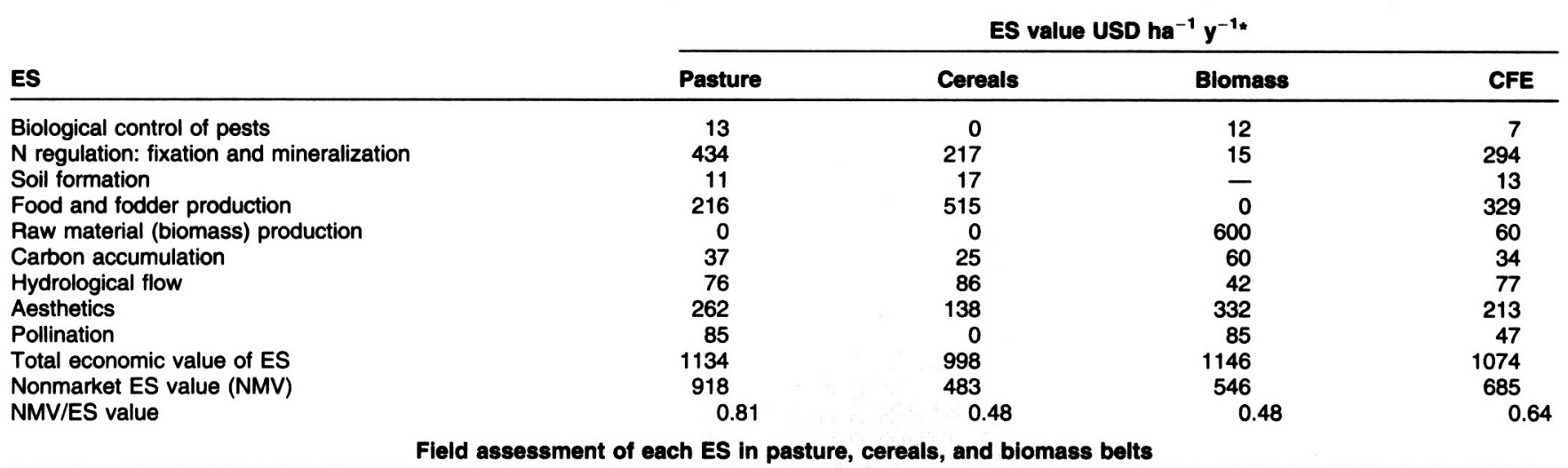

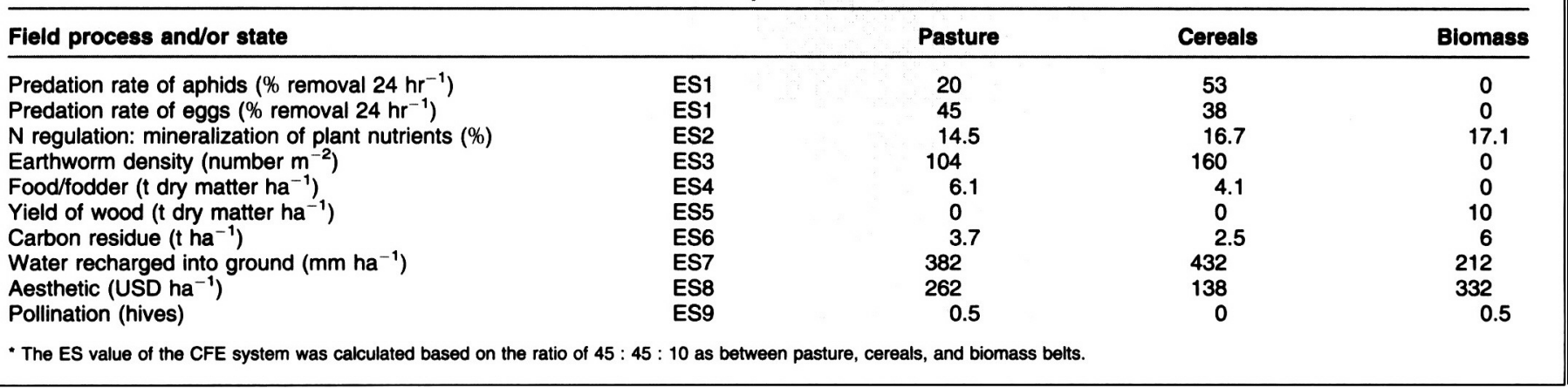


Table 4. ES values of six scenarios of land use in the EU25 countries based on the current land use, $100 \%$ arable or $100 \%$ pasture cover, and percentages $(10 \%, 20 \%$, and $30 \%)$ CFE coverage of land. External costs (EC) were calculated based on Pretty et al. (11), but ignoring costs attributed to a single outbreak of bovine spongiform encephalopathy. For comparison, public subsidy values of agriculture for the EU25 countries range from USD $133 \times 10^{9} \mathrm{y}^{-1}$ to USD $150 \times 10^{9} \mathrm{y}^{-1}$.

ES value (USD $\left.\times 10^{9}\right)$

\begin{tabular}{|c|c|c|c|c|c|c|}
\hline Scenario & MV & NMV & TES : (M + NMV) & EC & TES-EC & NMV/TES \\
\hline Current & 68 & 126 & 194 & 52 & 142 & 0.65 \\
\hline $100 \%$ arable & 99 & 94 & 193 & 66 & 127 & 0.49 \\
\hline $100 \%$ pasture & 33 & 177 & 210 & 29 & 181 & 0.84 \\
\hline CFE $(10 \%)$ & 57 & 139 & 196 & 42 & 154 & 0.71 \\
\hline CFE $(20 \%)$ & 58 & 140 & 197 & 38 & 160 & 0.72 \\
\hline CFE $(30 \%)$ & 54 & 145 & 199 & 33 & 166 & 0.73 \\
\hline
\end{tabular}

$M V=$ market valued $E S ; N M V=$ nonmarket valued $E S ; T E S=$ total $E S$ value

Food Production (ES4). Yields of grains and pastures were measured for 2006 , and the economic value was calculated as the farm gate prices of these products to give totals of USD 216 $\mathrm{ha}^{-1}$ (pasture) and USD $515 \mathrm{ha}^{-1}$ (crops).

Raw Material Production (ES5). Biomass belts provide wood for energy and power, and their economic value was calculated as the farm gate prices of wood for a combined heat and power generation plant as USD $600 \mathrm{ha}^{-1}$ at USD $60 \mathrm{t}^{-1}$.

Carbon Accumulation (ES6). The amount of plant and root residue was estimated in each CFE category as 1.5 times the crop grain yield, with $40 \%$ of this being carbon (43). This was used to calculate the economic value of carbon accumulation in each category. The economic value of carbon accumulated by crop and root residue was estimated based on USD $10 \mathrm{t}^{-1}$ of carbon accumulated (45).

Hydrological Flow (ES7). The economic value of this ES was calculated by estimating the input (rainfall and irrigation) and output of water (46) and the amount of water that was recharged into the ground in each category (47). The cost of applying water was calculated at the rate of USD 20 for $100 \mathrm{~mm}$ water $\mathrm{ha}^{-1}$. The water recharged into the ground is estimated and valued from the cost of applying water to give the economic value of this ES for each field.

Aesthetics (ES8). There was no direct method available to estimate the economic value of this ES. However, estimation of the aesthetic value of landscape on Swedish arable farms (48) were found to be USD 138, 262, and 332 ha $y^{-1}$ for cereals, pastures, and wooded arable landscapes, respectively, by using a contingent valuation method. We used these values as a standard value of aesthetic services provided by Danish arable farms, because they are similar to Swedish arable farms. Other methods, for example, willingness to pay, and other regions, such as the Yorkshire Dales National Park (UK) were found to have aesthetically based landscape values of about USD $140 \mathrm{y}^{-1}$ (49) (2006 prices), but we chose the Scandinavian values as more representative of landscape appreciation in Denmark and the relatively high land prices in this country.

Pollination (ES9). The economic value of this ES was estimated by using the direct cost incurred by farmers to buy a pollination service by hiring honey-bee hives for the period of pollination. The economic value of this ES is considered as zero for the fields where the crops do not require pollinators. Crops that require pollination cover about $30 \%$ of the CFE system, and this level of pollination could be provided by one hive of bees, which costs USD $170 \mathrm{y}^{-1}(50)$ and is partitioned equally between the clover pasture and biomass belts.

The whole notion of using nature's services or ES on farmland is to replace external inputs that have high external costs (11). The economic value of these ES on farmland provides useful information that can be used for maintenance and enhancement of these ES. The values estimated in this study by using bottom-up experimental methods are within the range reported in the literature (10).

\section{Caveats of These Methods}

Estimation of the economic value of ES in this study is limited for a number of reasons:

i) These methods assessed ES as a "snapshot" in time, but, as more and better information becomes available, better estimates of the total value of these ES can be obtained, and how they may change with time.

ii) There is evidence that ground-level predation in some crops can reduce pest populations to such an extent that a yield increase results (51). This was not accounted for in this study. Also, the level of biological control estimated in this study is based on only one of the many ecological guilds of predators and parasitoids that are potentially active in crops, so the potential total value of biological control in arable fields is likely to be higher than the minimal value presented here.

iii) The predation rates recorded in this study with "prey surrogates" provided useful estimates of the phenomenon of predation, given that use of living, mobile prey is technically very difficult. Absolute rates of predation calculated here may not accurately reflect real field rates. However, they do provide a useful comparative measure $(19,20,51)$.

iv) We attempted to use the best possible method to rapidly assess $N$ regulation (ES2) at the field level. However, this method only gives a relative measurement of rates. As other methods become available, we expect a better estimate of this ES.

v) Extrapolation from bait removal to $\mathrm{N}$ mineralization is being considered here based on a study by Kratz (31). This can only be considered as a crude approximation and introduces errors, depending on several factors, such as temperature, moisture content, $\mathrm{pH}$, and compaction of soil. However, it provides a useful estimate. Some studies (52) noted higher $\mathrm{N}$ mineralization rates than the ones obtained in this study.

\section{Calculation of the ES of EU Supported Agricultural Primary Production}

To calculate the ES of current and possible future land use in the EU25, we examined six scenarios of current and possible land use in European farming, the results of which are reported in Table 4. The scenarios were the following: $i$ ) the current EU25 areas of arable and pasture as defined by statistics from the Food and Agriculture Organization (53), ii) a scenario in which all cultivated land was used for arable cereal production, iii) that all cultivated land was used for pasture, $i v$ ) a scenario 
that $10 \%$ of the area was used for bioenergy production (as in the CFE system), and $v, v i$ ) scenarios in which $20 \%$ and $30 \%$ of the area was used for bioenergy production, respectively. ES were divided into market valued services (MV, food and raw material production) and nonmarket valued services (NMV). The external costs of arable- and pasture-based production in Europe, valued in 2000 at USD $387 \mathrm{ha}^{-1}$ and USD $172 \mathrm{ha}^{-1}$, respectively (11), were subtracted from the NMV ES values to give a net value of nonmarket ES. These calculations excluded external costs (11) attributed to the single outbreak of bovine spongiform encephalopathy, because this was a one-off case.

\section{RESULTS}

\section{Field-based Value of ES}

We took a "bottom-up" approach to estimating the ES of the CFE system, which meant that we measured field-scale processes and states of the system and then translated these functional elements into monetary terms by using willingness to pay, value transfer, and $\mathrm{AC}$ estimates. In the 2006 season, we made measurements of pest biocontrol and crop yields and measurements of plant nutrient mineralization, earthworm density and soil formation, $\mathrm{N}$ fixation, and insect pollination to obtain a "snapshot" of the ES from the CFE system 11 years after the it started. The total and nonmarket economic values of ES for each of the three components of the CFE system were calculated separately (Table 3 ).

Local measurements of ecological processes in the CFE system and their valuation show (Table 3 ) that, of the three components of the CFE system (biomass, cereals, and pastures), the biomass had the highest gross ES (USD $1146 \mathrm{ha}^{-1}$ ), followed by the pasture (USD $1134 \mathrm{ha}^{-1}$ ) and crops (USD 998 $\mathrm{ha}^{-1}$ ), respectively. Nonmarket ES make up $48 \%, 48 \%$, and $81 \%$ of the total ES of the three CFE components, respectively. When account is taken of the proportional areas of the pasture $(45 \%)$, cereals $(45 \%)$, and biomass $(10 \%)$, the ES of the CFE system as a single unit is USD $1074 \mathrm{ha}^{-1}$, of which $64 \%$ is nonmarket. By using globally derived figures (1) and including multifunctional ES raises the gross value of ES from cropping agriculture from USD $92 \mathrm{ha}^{-1}$ (1) (comprising pollination [USD $14 \mathrm{ha}^{-1}$ ], biological control [USD $24 \mathrm{ha}^{-1}$ ], and food provision [USD $54 \mathrm{ha}^{-1}$ ]) to USD $1866 \mathrm{ha}^{-1}$, with the net value USD 1479 $\mathrm{ha}^{-1}$ when external costs (being USD $387 \mathrm{ha}^{-1}$ ) (11) are included. Thus, both locally and globally based calculations of ES from multifunctional farming point to a net value of ES from agriculture of between USD 1000 and $1500 \mathrm{ha}^{-1}$. The largest contributions to multifunctional agriculture's ES come from the regulation of $\mathrm{N}$ turnover, food and raw material production, and a contribution to landscape aesthetics.

\section{Extrapolation of Results to Regional and European Scales}

In 2006, the EU comprised 25 countries, with an arable area of 104.2 million ha and a pasture area of 66.3 million ha. Based on the estimations of economic value of ES from the CFE system and its cereals, pasture, and biomass areas, the total and nonmarket value of ES was calculated for the EU25 arable and pasture area. Then, based on scenarios that the EU biomass area might increase to $30 \%$ of the total, market and nonmarket ES values were calculated. Total economic and nonmarket values of ES in the EU25 were calculated based on the values obtained in CFE system.

The current spatial pattern of agricultural primary production in the EU25 is calculated to yield a net ES value of USD $142 \times 10^{9}$ (Table 4), with current total societal transfers to farming that ranged from USD $133.8 \times 10^{9}$ to USD $150.5 \times 10^{9}$. The higher of the two figures includes societal support to farming, such as education and other peripheral services; the lower value refers purely to production support. A wholly pastoral EU25 primary production raises the net ES to USD $181 \times 10^{9}$, whereas wholly arable-based production lowers it to a predicted USD $127 \times 10^{9}$ (Table 4). Our estimates of the value of market valued EU25 ES in Table 4 (USD $68 \times 10^{9}$ ) are very close to the current total farm-gate prices for crops and pasture products (USD $70 \times 10^{9}$ ) reported in European agricultural statistics (54), which adds confidence to our independently derived estimates of other European agricultural ES.

Extrapolating the current CFE system to the EU25, to a scenario in which $10 \%$ of the agricultural area is devoted to bioenergy production, would raise the total net ES above its current value, and this trend continues with increasing allocations of agricultural area to bioenergy. With $30 \%$ of the land area covered with CFE-like bioenergy systems, the predicted net ES rises to USD $166 \times 10^{9}$, a value well above current subsidy levels. The limit of $30 \%$ conversion to bioenergy that produces agro-ecosystems is commensurate with other estimates of the available land for biomass in the EU (55). The overall picture is that societal support for farming in the EU25 countries is close to the calculated current nonmarket ES provision and that nonmarket ES can be raised by favoring agro-ecosystems that include perennial or semiperennial elements (56). We ignored European regional climatic effects on agro-ecosystem processes and ES and the effects that substantial changes in EU25 land use could have on world commodity prices and the subsequent feedbacks on European food production.

\section{DISCUSSION}

\section{ES in Relation to Agricultural Subsidies in Europe}

Agricultural subsidy levels to Organisation for Economic Cooperation and Development (OECD) countries are available from the OECD Web site (57). Since 2005, data for the EU have been for the 25 countries that comprised the EU in 2005 (EU25). The OECD uses a variety of statistics in presenting measurements of support to agriculture. These comprise the Producer Support Estimate (PSE), the Consumer Support Estimate (CSE), the General Services Support Estimate (GSSE), and the Total Support Estimate (TSE), which is the sum of the other three. According to the OECD definition, the PSE is "an indicator of the annual monetary value of gross transfers from consumers and taxpayers to support agricultural producers, measured at the farm gate level, arising from policy measures which support agriculture, regardless of their nature, objectives or impacts on farm production or income." CSE is defined as the monetary value of transfers from consumers of agricultural commodities to producers and vice versa. GSSE covers other disbursements to agriculture, such as education, plant and animal health inspection services, etc. Formally, the TSE is "an indicator of the annual monetary value of all gross transfers from taxpayers and consumers arising from policy measures which support agriculture, net of associated budgetary receipts, regardless of their objectives and impacts on farm production and income, or consumption of farm products." According to the OECD, if a policy transfers funds to and/or from consumers of agricultural commodities, then this is considered a subsidy under the CSE; if the policy measure creates a transfer to producers individually based on goods and services produced from a farm, then it is considered a PSE; if a policy transfers funds to general services provided to agriculture collectively, then it is considered under GSSE.

Because we are concerned with the production of goods and services from the agricultural sector in the EU25, we chose to 
compare ES values of arable, pasture, and CFE agroecosystems with the PSE and TSE values reported by the OECD on their Web site (57). The TSE value for EU25 countries in 2005 was USD $150.5 \times 10^{9}$ and that for PSE was USD $133.8 \times 10^{9}$.

\section{Combined Food, Energy, and Ecosystem Services}

The Millennium Assessment (58) reported a loss of ES worldwide, and more recent reports $(5,59)$ advocate designing production systems that can contribute to global ES. The CFEES agro-ecosystem discussed in this study provides a novel way of producing food, fodder, energy in the form of renewable biomass, and ES. Field-based estimates of individual ES identified in this system provides conservative estimates of the economic value. The value of supporting services (biological control of pests, $\mathrm{N}$ regulation [fixation and mineralization], soil formation, carbon accumulation, and pollination) and regulating services (hydrological flow) is based on AC estimates. Provisioning services included food and fodder production and biomass production. Their value is based on farm-gate prices of produce. Aesthetics ES identified in this study as a cultural service was assessed by using value transfer, because no other estimate was available. Agri-environment schemes implemented in various EU countries do not effectively yield outcomes to balance farming activities and environmental outcomes (60). The CFEES system offers the scope to maintain this balance, and results obtained in this study support this (Table 3 ).

Agro-ecosystems are complex systems and produce multiple benefits, recognition of which led to the concept of ES. Important distinctions need to be made when the economic value of an ES is calculated. Many conventional economic activities and all ecosystems produce multiple goods and services (benefits) jointly or simultaneously. For example, a factory might produce both windows and doors as goods and ecosystems may simultaneously produce water regulation, carbon sequestration and recreation as services. Products and services can be counted individually and then added together to get an estimate of total goods and services. Counting value from separate ES as if they were aggregated only in a finally produced product, such as crop yield, abrogates the whole concept of ES as being distinct properties of how an ecosystem functions. In general, we counted the final product or service at the point that it provides benefits, and we tried to avoid double counting by not counting twice the inputs to a product or service. For example, the carbon from crop residues that is incorporated into the soil and counted as a carbon sequestration service is not included in determining the market value of the crops. In other words, we were careful not to count the same process as contributing to both a proxy and a final service, because that would be double counting.

In many countries, agriculture is subsidized by both the taxpayer and the consumer of agricultural products. It is fair to ask what society derives from its support of farming and whether this cost to society is commensurate with the damage caused by agriculture and the benefits obtained. Thus, after deriving field-based estimates of ES value, we extrapolated our results to the EU25 countries' conventional farming. This provided information on how ES value might change given a move toward CFE like agro-ecosystems with deliberately enhanced ES. In what follows, we excluded services indirectly dependent on farming in Europe but concentrate on the simple calculation of the value of beneficial services from production agriculture and see how these compare with societal support costs (Table 3).

For global ES to maintain or even increase their current value, agricultural systems have to be designed with ES in mind (61), such that nonmarket ES contribute between $50 \%$ and $70 \%$ of an agroecosystems total ES value (Tables 2 and 3). The CFEES approach is an example of such a system, but, one that is more pasture based is also likely to offer high nonmarket ES as a proportion of its value (Table 3 ). Converting conventional agriculture to CFEES agro-ecosystems could substantially and simultaneously enhance food, fiber, energy, and global ES production and sustainability. Future scientific challenges in this area need to examine and define, by using a range of approaches, the properties of agroecosystems that provide ES as so-called service providing units, defined as the population unit that provides an ecosystem service at some spatial or temporal scale (62), and to evaluate how ES may change with time through climate change and other influences (63) rather than by using simple "snapshots" in time. A socially desirable future goal would be to develop further the notion of the energy neutral farming systems, as represented by the CFE system, toward farming systems that are greenhouse gas neutral in the sense that losses of carbon and noncarbon greenhouse gases are balanced by carbon sequestration.

\section{References and Notes}

1. Costanza, R., d'Arge, R., de Groot, R., Farber, S., Grasso, M., Hannon, B., Limburg K., Naeem, S., et al. 1997. The value of the world's ecosystem services and natural Capital. Nature $387,253-260$.

2. Bjorklund, J., Limburg, K.E. and Rydberg, T. 1999. Impact of production intensity on the ability of the agricultural landscape to generate ecosystem services: an example from Sweden. Ecol. Econ. 29, 269-291.

3. Economics for the Environmental Consultancy. 2005. The Economic, Social and Ecological Value of Ecosystem Services. (http://jncc,gov,uk/page-4025)

4. Porter, J.R. 2003. Multifunctionality and ecosystem services in European agriculture. Paper presented at the International Conference on Ecosystem Services in European Agriculture: Theory and Practice in Cooperation with the Bertebos Foundation, 14-16 September, Falkenberg, Sweden.

5. Food and Agriculture Organization (FAO). 2007. The State of Food and Agriculture: Paying Farmers for Environmental Services. FAO Agriculture Series, No. 38, Rome, 222 Pp.

6. Organisation for Economic Cooperation and Development (OECD). 1999. Environmental Benefits from Agriculture: Issues and Policies. OECD, Paris.

Boody, G., Vondracek, B., Andow, D.A., Krinke, M., Westra, J., Zimmerman, J. and Welle, P. 2005. Multifunctional agriculture in the United States. BioScience 55, 27-38. Mooney, H., Cropper, A. and Reid, W. 2005. Confronting the human dilemma. Nature $434,561-562$.

9. Costanza, R. 2008. Ecosystem services: multiple classification systems are needed. Biol. Conserv. 141,350-352.

10. Sandhu, H.S., Wratten, S.D., Cullen, R. and Case, B. 2008. The future of farming: the value of ecosystem services in conventional and organic arable land. An experimental approach. Ecol. Econ. 64, 835-848.

11. Pretty, J.N., Ball, A.S. and Lang, T. 2005. Farm costs and food miles: an assessment of the full costs of the UK weekly food basket. Food Policy 30, 1-19.

12. Tilman, D.. Hill, J. and Lehman, C. 2006. Carbon-negative biofuels from low-input high-diversity grassland biomass. Science 314, 1598-1600.

13. Haas, G., Geier, U., Schulz, D.G. and Köpke, U. 1995. A comparison of conventional and organic agriculture. Part I. Climate relevant carbon dioxide emission from the use of fossil energy. Berichte über Landwirtschaft 73, 401-415.

14. Danish Environment Agency. 2006. Agricultural Chemical Statistics. (http:/www.mst. $\mathrm{dk} /$ udgiv/publikationer $/ 2006 / 87-7052-143-3 / \mathrm{htm} /$ helepubl.htm)

15. Danish Statistical Service. 2006. Denmarks Statistics. (http://www.dst.dk/nyt)

16. Pedersen, x.A. 2006. Summary of Agricultural Trials. Danish Agricultural Advisory

17. McTaggart, D., Findlay, C. and Parkin, M. 2003. Economics. Pearson Education, NSW

18. Daily, G.C. 1997. Nature's Services: Societal Dependence on Natural Ecosystems. Island Press, Washington, DC.

19. Ekbom, B.S., Wiktelius, S. and Chiverton, P.A. 1992. Can polyphagous predators control the bird cherry-oat aphid (Rhopalosiphum padi) in spring cereals? A simulation study. Entomol. Exp. Appl. 65, 215-223.

20. Winder, L., Hirst, D.J., Carter, N., Wratten, S.D. and Sopp, P.I. 1994. Estimating predation of the grain aphid Sitobion avenae by polyphagous predators. J. Appl. Ecol. $31,1-12$

21. Burn, A.J. 1982. The role of searching efficiency in carrot fly egg loss. Ann. Appl. Biol. $101,154-159$

22. Merfield, C.N., Wratten, S.D. and Navntoft, S. 2004. Video analysis of predation by polyphagous invertebrate predators in the laboratory and field. Biol. Control 29, 5-13.

23. Frank, S.D.. Wratten, S.D., Sandhu, H.S. and Shrewsbury, P.M. 2007. Video analysis to determine how habitat strata affects predator diversity and predation of Epiphyas postvittana (Lepidoptera: Tortricidae) in a vineyard. Biol. Control 41, 230-236.

24. de Groot, R.S., Wilson, M. and Boumans, R.M.J. 2002. A typology for the classification, description and valuation of ecosystem functions, goods and services. Ecol. Econ. 41, 393-408.

25. Wilson, M., Troy, M. and Costanza, R. 2004. The economic geography of ecosystem goods and services: revealing the monetary value of landscapes through transfer methods and geographic information systems. In: Cultural Landscapes and Land Use: the Nature Conservation-Society Interface. Dieterich, M. and van der Straaten, J. (eds). Kluwer Academic Publishers, Dordrecht, pp. 69-94.

26. Danish Agricultural Advisory Service. 2006. (http://www.lr.dk/middeldatabasen/ pricelist.asp)

27. Thies, C., Roschewitz, I. and Tscharntke. T. 2004. The landscape context of cereal aphid-parasitoid interactions. Proc. $R$. Soc. Lond. B Biol. Sci. 449, 1-8.

28. Luxhøi, J., Bruun, S., Stenberg, B., Breland, T.A and Jensen, L.A. 2006. Prediction of gross and net nitrogen mineralization - immobilization - turnover form respiration. Soil Sci. Soc. Am. J. 70, 1121-1128.

29. Eriksen, J. Vinther, F.P. and Soegaard, K. 2004. Nitrate leaching and N-2 fixation in grasslands of different composition, age and management. J. Agric. Sci. 142, 141-151. 
30. Myrold, D.D. and Huss-Danell, K. 2003. Alder and lupine enhance nitrogen cycling in a degraded forest soil in Northern Sweden. Plant Soil 254, 47-56.

31. Kratz, W. 1998. The bait-lamina test: general aspects, applications and perspectives Environ. Sci. Pollut. Res. 5, 94-96.

32. Torne, E. 1990. Assessing feeding activities of soil-living animals: I. Bait-lamina tests. Pedobiologia 34, 89-101.

33. Helling, B., Pfeiff, G. and Larink, O. 1998. A comparison of feeding activity of collembolan and enchytraeid in laboratory studies using the bait-lamina test. Appl. Soil Ecol. 7, 207-212.

34. Weil, R. and Magdoff, F. 2004. Significance of soil organic matter to soil quality and health. In: Soil Organic Matter in Sustainable Agriculture. Magdoff, F. and Weil, R. (eds). CRC Press, Boca Raton, Florida, pp. 1-43

35. Poudel, D.D., Horwath, W.R., Mitchell, J.P. and Temple, S.R. 2001. Impacts of cropping systems on soil nitrogen storage and loss. Agric. Sys. 68, 253-268

36. Benbi, D.K. and Richter, J. 2002. A critical review of some approaches to modelling nitrogen mineralization. Biol. Fertil. Soils 35, 168-183.

37. Hamel, C., Schellenberg, M.P., Hanson, K. and Wang, H. 2007. Evaluation of the "baitlamina test" to assess soil microfauna feeding activity in mixed grassland. Appl. Soil Ecol. $36,199-204$.

38. Brady, N.C. 1990. The Nature and Properties of Soils. Macmillan Publishing Company, New York.

39. Martin. N.A. 1978. Earthworms in New Zealand agriculture. Proceedings of the 31 New Zealand Weed and Pest Control Conference. New Zealand Plant Protection Press, New Plymouth, pp. 176-180.

40. Beare, M. 2001. Soil Quality Management System User Manual. New Zealand Institute for Crop and Food Research Limited, Christchurch.

41. Phillipson, J., Abel, R., Steel, J. and Woodell, S.R.J. 1978. Earthworm numbers, biomass and respiratory metabolism in a Beech Woodland-Wytham Woods, Oxford. biomass and respiratory

42. Fraser, P.M., Williams, P.H. and Haynes, R.J. 1996. Earthworm species, population size and biomass under different cropping systems across the Canterbury Plains, New Zealand. Appl. Soil Ecol. 3, 49-57.

43. Pimentel, D., Harvey, C., Resosudarmo, P., Sinclair, K., Kurz, D., McNair, M., Cris S.. Shpritz, L., et al. 1995. Environmental and economic costs of soil erosion and conservation benefits. Science 267, 1117-1125.

44. Johnson, J.M.F., Allmaras, R.R. and Reicosky, D.C. 2006. Estimating source carbon from crop residues, roots and rhizodeposits using the national grain-yield database Agron. J. 98, 622-636.

45. Capoor, K. and Ambrosi, P. 2006. State and Trends of the Carbon Market 2006. The World Bank, Washington, DC

46. Pimentel, D., Houser, J., Preiss, E., White, O., Fang, H., Mesnick, L., Barsky, T. Tariche, S.. et al. 1997. Water resources: agriculture, the environment, and society Bioscience 47, 97-106.

47. Allen, R.G., Pereira, L.S., Raes, D. and Smith, M. 1998. Crop evapotranspiration guidelines for computing crop water requirements. FAO Irrigation and Drainage, Paper 56 , Rome.

48. Drake, L. 1992. The non-market value of the Swedish agricultural landscape. Eur. Rev. Agric. Econ. 19, 351-364.

49. Willis, K.G. and Garrod, G.D. 1993. Valuing landscape: a contingent valuation approach. J. Environ. Manage. 37, 1-22.

50. Danish Beekeepers Association. 2006. (http://www.biavl.dk)

51. Östman, Ö., Ekbom, B. and Bengston, J. 2003. Yield increase attributable to aphid predation by ground-living polyphagous natural enemies in spring barley in Sweden. Ecol. Econ. 45, 149-158.

52. de Neve, S. Hartmann, R and Hofman, G. 2003. Temperature effects on mineralization: changes in soil solution composition and determination of temperature coefficients by TDR. Eur. J. Soil Sci. 54, 49-61.

53. FAO 2007. The Statistics Division. (http//www fao org/statistics)

54. European Statistical Office 2006. Agricultural Statistics. (htis) eu)

55. Doornbosch, R. and Steenblik, R. 2007. Biofuels: Is the Cure Worse than the Disease? OECD, Paris.

56. Sandhu, H.S. 2007. Quantifying the Economic Value of Ecosystem Services on Arable Farmland: A Bottom-Up Approach. PhD thesis, Lincoln University, New Zealand.

57. Organisation for Economic Cooperation and Development. 2006. (http://www.oecd.org topicstatsportal/0,2647,en_2825_494504_1_1_1_1_1,00.html)
58. Reid, W.V., Mooney, H.A., Croppe, A., Capistrano, D., Carpenter, S.R., Chopra. K. Dasgupta, P., Dietz, T., et al. 2005. Millennium Ecosystem Assessment Synthesis Report. Island Press, Washington, DC.

59. Steinfield, H., Gerber, P., Wassenaar, T., Castel, V., Rosales, M. and de Haan, C. 2006 Livestock's Long Shadow: Environmental Issues and Options. Livestock, Environment and Development Initiative. FAO, Rome.

60. Kleijn, D., Berendse, F., Smit. R. and Gilissen, N. 2001. Agri-environment schemes do not effectively protect biodiversity in Dutch agricultural landscapes. Nature 413, 723 725 .

61. Foley, J.A., deFries, R., Asner, G.P., Barford, C., Bonan, G., Carpenter, S.R. Chapin F.S., Coe, M.T., et al. 2005. Global consequences of land use. Science 309, 570-573.

62. Luck, G.W. Daily, G.C. and Ehrlich, P.R. 2003. Population diversity and ecosystem services. Trends Ecol. Evol. 18, 331-336.

63. Schröter, D., Cramer, W., Leemans. R., Prentice, I.C., Araújo, M.B., Arnell, N.W. Bondeau, A., Bugmann. H., et al. 2005. Ecosystem service supply and vulnerability to global change in Europe. Science 310, 1333-1337.

64. First submitted 16 July 2008 . Accepted for publication 13 January 2009.

John Porter is a professor of agroecology at the University of Copenhagen. His address: the Department of Agricultural Sciences, Faculty of Life Sciences, University of Copenhagen (KU-LIFE), Højbakkegård Alle 9, 2630 Taastrup, Denmark. E-mail: jrp@life.ku.dk

Robert Costanza is the Gund Professor of Ecological Economics and director of the Gund Institute for Ecological Economics at the University of Vermont. His address: Gund Institute for Ecological Economics, Rubenstein School of Environment and Natural Resources, University of Vermont, VT 05405-1708, USA.

E-mail: rcostanz@zoo.uvm.edu

Harpinder Sandhu is a research scientist (ecologist) at CSIRO Sustainable Ecosystems. His address: CSIRO Sustainable Ecosystems, Waite Road, Private Bag No. 2, Glen Osmond SA 5064, Australia.

E-mail: Harpinder.Sandhu@csiro.au

Lene Sigsgaard is an associate professor at KU-LIFE. Her address: Department of Ecology, KU-LIFE, Thorvaldsensvej 40, 1871 Frederiksberg, Denmark.

E-mail: les@life.ku.dk

Steve Wratten is a professor of ecology at Lincoln University. His address: the National Centre for Advance Bio-Protection Technologies, Lincoln University, PO Box 84, Lincoln 7647, New Zealand.

E-mail: Steve.Wratten@lincoln.ac.nz 